\title{
Protein Lipidation As a Regulator of Apoptotic Calcium Release: Relevance to Cancer
}

\author{
Jessica J. Chen and Darren Boehning * \\ Department of Biochemistry and Molecular Biology, McGovern Medical School, UTHealth, Houston, TX, United States
}

Calcium is a critical regulator of cell death pathways. One of the most proximal events leading to cell death is activation of plasma membrane and endoplasmic reticulumresident calcium channels. A large body of evidence indicates that defects in this pathway contribute to cancer development. Although we have a thorough understanding of how downstream elevations in cytosolic and mitochondrial calcium contribute to cell death, it is much less clear how calcium channels are activated upstream of the apoptotic stimulus. Recently, it has been shown that protein lipidation is a potent regulator of

OPEN ACCESS

Edited by:

Cesar Cardenas,

Universidad de Chile, Chile

Reviewed by:

Olivier Micheau,

Institut national de la santé et de la recherche médicale (INSERM), France

Catherine Brenner Jan, Institut national de la santé et de la recherche médicale (INSERM), France

*Correspondence: Darren Boehning darren.f.boehning@uth.tmc.edu

Specialty section: This article was submitted to Molecular and Cellular Oncology,

a section of the journal

Frontiers in Oncology

Received: 12 April 2017 Accepted: 16 June 2017 Published: 29 June 2017

Citation:

Chen JJ and Boehning D (2017)

Protein Lipidation As a Regulator of Apoptotic Calcium Release:

Relevance to Cancer.

Front. Oncol. 7:138.

doi: 10.3389/fonc.2017.00138 apoptotic signaling. Although classically thought of as a static modification, rapid and reversible protein acylation has emerged as a new signaling paradigm relevant to many pathways, including calcium release and cell death. In this review, we will discuss the role of protein lipidation in regulating apoptotic calcium signaling with direct therapeutic relevance to cancer.

Keywords: calcium, apoptosis, lipidation, Fas, cancer, inositol phosphates, kinases, statins

\section{INTRODUCTION}

Apoptotic cell death is important for embryonic development and tissue homeostasis, and dysfunction of this pathway can contribute to various disease states, including cancer. The intrinsic apoptosis pathway is activated by cellular stress and leads to $\mathrm{Bcl}-2$ protein activation, mitochondrial membrane permeabilization, and release of proapoptotic proteins $(1,2)$. In addition to their roles in mitochondrial membrane permeabilization, $\mathrm{Bcl}-2$ family proteins are also essential and direct regulators of intracellular calcium during apoptosis by binding to a surprising variety of channels, pumps, and exchangers (3-11). Elevated cytosolic calcium then contributes to the apoptotic program in a multitude of ways including mitochondrial permeabilization and further activation of proapoptotic Bcl-2 proteins (12).

The extrinsic apoptosis pathway is activated by ligand binding to death receptors of the tumor necrosis factor- $\alpha$ (TNF $\alpha$ ) superfamily. Ligand binding to the death receptor results in the activation of the initiator caspases 8 and $10(13-15)$. Caspase $8 / 10$ can directly cleave and activate effector caspases and/or cleave the proapoptotic Bcl-2 family protein Bid. Truncated Bid leads to mitochondrial permeabilization and release of proapoptotic proteins (16). Cell which do not engage the mitochondrial pathway are called "type I" cells, and those which lead to mitochondrial permeabilization are called "type II" cells (17). Thus, in type II cells the extrinsic pathway converges with the intrinsic pathway at the mitochondria. Calcium also contributes to the progression of the extrinsic pathway (18-21); however, this is less well understood.

Recently, it has been found that multiple proteins which regulate apoptotic calcium release in both the intrinsic and extrinsic pathways are subject to lipidation. Protein lipidation is the cotranslational 
or posttranslational covalent addition of a variety of lipids, including fatty acids, isoprenoids, and cholesterol, to target proteins. Such modifications regulate protein localization and function in many signaling processes. Recent advances in detecting lipidated proteins by proteomic and targeted approaches have revealed that lipidation of signaling proteins is essential for regulating a wide variety of signaling pathways. Stimulus-dependent lipidation of the apoptotic machinery is likely a central regulator of cell death, and defects in this pathway may be contributing factors in cancer development. In this review, we will discuss how protein lipidation plays an essential role in apoptotic signaling and the relevance to cancer therapeutics.

\section{TYPES OF LIPIDATION}

Lipidation can be categorized into two types based on the location of the modified proteins: those that are modified in the ER lumen and secreted and those that are modified in the cytoplasm or on the cytoplasmic face of membrane (22). The former type includes glycosylphosphatidylinositol (GPI) anchor and cholesterylation, and the latter includes $\mathrm{N}$-myristoylation, acylation, and prenylation.

Glycosylphosphatidylinositol anchor was first discovered in the parasite Trypanosoma brucei where the highly expressed variant surface glycoprotein is anchored to the cell surface via a glycolipid containing phosphatidylinositol (23-25). Since then, many proteins in mammals and lower eukaryotes such as protozoa have been shown to contain GPI anchors with enormous structural variety, most of which include an ethanolamine attached to the carboxyl terminus of the protein, a glycan core, inositol, and lipid moieties (26-28). GPI-anchored peptides often include a cleavable $\mathrm{N}$-terminal signal sequence, which directs the peptide to ER lumen, and a hydrophobic C-terminal sequence that is cleaved at the time of GPI anchor addition $(27,29,30)$. GPI anchors facilitate tethering of proteins to the extracellular face of the plasma membrane and are important for many cellular functions, including adhesion, membrane trafficking, and immune system signaling (31-33).

Cholesterylation is a characteristic of the mammalian Hedgehog family, which are secreted signaling proteins that regulate embryonic patterning of many tissues and structures $(34,35)$. The Hedgehog protein undergoes an autocatalytic processing that internally cleaves between the conserved Gly ${ }^{257}$ and $\mathrm{Cys}^{258}$ at the GCF motif and yields a $\sim 20 \mathrm{kDa}$ N-terminal signaling domain and a $\sim 25 \mathrm{kDa}$ C-terminal catalytic domain $(36,37)$. The $\mathrm{N}$-terminal domain receives a cholesterol moiety and is active in signaling $(35,37,38)$. Interestingly, multiple studies have detected other potentially cholesterylated proteins $(35,39)$. However, the identification of these potential cholesterylation targets remains to be elucidated.

$\mathrm{N}$-myristoylation is the attachment of the 14-carbon myristic acid to an N-terminal Gly residue via an amide bond (40). It was first identified as a blocking group that prevents Edman degradation on the $\mathrm{N}$-terminus of the catalytic subunit of cyclic AMP-dependent protein kinase and the calcium-binding $\beta$-subunit of calcineurin $(41,42)$. Many other proteins regulating key signaling pathways, including the Src family non-receptor protein tyrosine kinases $(43,44)$ and $\mathrm{G}_{\alpha}$ proteins $(45,46)$ were shown to be myristoylated. These proteins contain the $\mathrm{N}$-terminal sequence Met-Gly- and often have a Ser/Thr/Cys at position 6 $(40,47)$. Myristoylation can happen cotranslationally following the removal of the initiator methionine residue (48). Although myristoylation is required for membrane targeting of many proteins, it is not sufficient for stable membrane anchoring due to its weak hydrophobic nature and often needs subsequent lipid modifications (49-51). Additionally, myristoylation can also happen posttranslationally during apoptosis following the caspase cleavage of substrate proteins that exposes an internal glycine (52-55). Many apoptotic proteins, including Bid, gelsolin, and p21-activated kinase 2, require posttranslational myristoylation following caspase cleavage for proper subcellular localization and subsequent functions (52-54).

Acylation is the addition of various fatty acids, such as palmitic acid, oleic acid, and stearic acid, on different amino acid residues (56-58). One of the best studied types of acylation is $\mathrm{S}$-palmitoylation, which is characterized by the reversible addition of the 16-carbon saturated palmitic acid to Cys residues via labile thioester bonds $(58,59)$. Despite the presence of multiple algorithms to predict palmitoylation sites, there is no validated consensus sequence for palmitoylation (60-62). One key aspect of palmitoylation is that its reversibility allows for a palmitoylation and depalmitoylation cycle that regulates the posttranslational trafficking and functions of target proteins, such as $\mathrm{H}$ - and N-Ras (63). Palmitoylation can also occur on large transmembrane proteins, including ion channels and $G$ protein-coupled receptors (64-68). The roles of transmembrane protein palmitoylation include regulation of channel maturation/quality control and association with lipid rafts (69-72).

Prenylation is the addition of the 15-carbon farnesyl or the 20-carbon geranylgeranyl isoprenoid lipid on cysteine residues via stable thioether bonds $(73,74)$. It requires a C-terminal CAAX motif, where $\mathrm{C}$ is a cysteine, $\mathrm{A}$ is aliphatic amino acids, and $\mathrm{X}$ can be any amino acid. Prenylation at the CAAX motif is found in many proteins, including mammalian Ras proteins $(75,76)$. In addition to its role in membrane association, prenylation can also regulate protein-protein interaction and subcellular distribution of the modified targets $(77,78)$.

\section{ENZYMATIC REGULATORS OF PROTEIN LIPIDATION}

Protein lipidation is catalyzed by specific enzymatic regulators crucial for the addition (and removal in the case of S-acylation) of the lipid moieties. The GPI precursor, formed in ER lumen, is transferred to target proteins by GPI transamidase, a membranebound multi-subunit enzyme (79-82). GPI transamidase cleaves the C-terminal signal peptide of the target proteins, and forms an enzyme-substrate intermediate, allowing the nucleophilic attack by the terminal amino group of preformed GPI (83). On the other hand, cholesterylation of the $\mathrm{N}$-terminal signaling domain of Hedgehog seems to be only dependent on the presence of the C-terminal catalytic domain, suggesting that this process is autocatalytic (35). 
$\mathrm{N}$-myristoylation is catalyzed by $\mathrm{N}$-myristoyltransferases (NMTs) (84-86). NMTs bind first to myristoyl-CoA and then to the peptide, followed by a direct nucleophilic addition-elimination reaction and subsequent release of $\mathrm{CoA}$ and the myristoylated peptide (87). Studies in various tissues and cell types have shown that the enzymatic activity of NMTs is predominantly distributed in the cytosolic fraction (88-91). Some studies have shown that low levels of myristoyl-CoA may be rate limiting for NMT activity $(92,93)$. However, the transcriptional upregulation of NMT under pathological conditions suggests that this might not always be the case (94).

Protein S-acylation is regulated by palmitoyl acyltransferases (PATs) that catalyze lipid attachment to cysteine residues and acyl-protein thioesterases (APTs), which remove them. There are 23 PATs in mammals, all of which share a common DHHC (AspHis-His-Cys) motif within a cysteine-rich domain $(95,96)$. PATs are polytopic membrane proteins that are localized to distinct subcellular compartments, primarily the Golgi apparatus and the plasma membrane (97). Some DHHC enzymes show preference for certain types of proteins (i.e., transmembrane proteins), and in some cases the same substrates can be palmitoylated by multiple DHHC enzymes $(95,98-100)$. Compared to the large amount of studies on PATs, thioesterases are relatively poorly characterized. Two protein palmitoyl thioesterases (PPT1/2) and two APTs (APT1/2) have been identified (101-104). PPTs predominantly localize to the lysosomal lumen and are involved in depalmitoylation during protein degradation, whereas APTs have cytosolic localization and are shown to depalmitoylate and recycle signaling proteins such as Ras and growth associate protein (GAP-43) from the plasma membrane back to Golgi (102-105). Very recently, two independent groups found that the $\alpha / \beta$ hydrolase fold (ABHD) family of serine hydrolases is potent depalmitoylating enzymes for select substrates, including PSD-95 and N-Ras $(106,107)$.

Prenylation is catalyzed by the enzymes farnesyltransferase (FTase), geranylgeranyltransferase I (GGTase 1), and Rab geranylgeranyltransferase (GGTase 2) (108-110). The prenylating enzymes localize to the cytosol and conjugate isoprenoids generated from mevalonate/HMG-CoA reductase pathway to target proteins. Specifically, the isoprenoids farnesyl and geranylgeranyl are transferred to a C-terminal CAAX motif on target proteins. Unlike FTase and GGTase 1, geranylgeranyl transfer by GGTase 2 requires the co-factor REP (Rab escort protein) (111). GGTase 1 and FTase generally have high specificity for the protein targets, depending on the $\mathrm{X}$ residue (112-114). However, they can act on each other's substrates. One example is that K-Ras and $\mathrm{N}$-Ras, usually targets of FTase, can be geranylgeranylated in Rasmutant human cancer cells treated with FTase inhibitors (115, 116). Removal of the -AAX tripeptide and methylation of the prenyl-cysteine, catalyzed by the ER membrane proteins RCE1 and ICMT, respectively, are two post-prenylation steps required for maturation of prenylated proteins (117-119).

\section{LIPIDATION AND APOPTOTIC CALCIUM RELEASE}

As noted in the Section "Introduction," calcium regulates many cellular processes and plays a prominent role in cell death signaling. Both intrinsic (12, 120-122) and extrinsic (18-21, 123) apoptotic stimuli lead to cytosolic, nuclear, and mitochondrial calcium elevations, which contribute to the execution of the apoptotic program. It is well known that many proteins that regulate cytosolic calcium and apoptotic calcium release are also subject to lipidation including pumps (124), exchangers (125), channels (126), and regulatory proteins (127). Perhaps best studied is protein palmitoylation due to the proliferation of proteomic studies using acyl-biotin exchange ( $\mathrm{ABE}$ ) to identify fatty-acylated proteins (128). Proteins are often assumed to be palmitoylated in $\mathrm{ABE}$ experiments, but clearly other lipids may also be conjugated with a thioester bond to target protein cysteine residues (129).

In order to understand how palmitoylation contributes to apoptotic calcium signaling, it is worthwhile to considering the kinetics of the enzymatic machinery. In many proteins which do not have a transmembrane domain, $\mathrm{N}$-terminal myristoylation precedes palmitoylation (130). Over 15 years ago, it was shown that $\beta$-adrenergic stimulation resulted in rapid palmitoylation $(130,131)$ or depalmitoylation (132) of $\mathrm{G}_{\alpha s}$. The model was based upon availability of free $G_{\alpha s}$ : dissociation from the $\beta \gamma$ subunits allowed putative palmitoylating and depalmitoylation enzymes access to the protein. Under this model, regulated palmitoylation and depalmitoylation cycles would be restricted to proteins which, under physiologic conditions, had regulated exposure of potential palmitoylation sites. Indeed, $\mathrm{G}_{\alpha \mathrm{s}}$ is one of only a very select few proteins in which direct palmitoylation within minutes of cellular stimulation has been conclusively determined [although other proteins such as PSD-95, eNOS, and Ras clearly have much higher turnover of palmitoyl groups in response to various stimuli, suggesting rapid cycling of lipid (133)].

Many proteins associated with cell death signaling are modified by lipids. Our group (18) and others (134-137) have investigated the role of palmitoylation in regulating death receptor signaling. We found that components of the $\mathrm{T}$ cell receptor (TCR) complex, such as Lck, Zap-70, PLC- $\gamma 1$ and other TCR components were required for apoptotic calcium release in T cells after engagement of the Fas receptor with Fas ligand (19). The Src kinase Lck is myristoylated and doubly palmitoylated on the N-terminus, and this regulates plasma membrane localization and partitioning into lipid rafts. It is known that the Fas macromolecular complex assembles and signals in lipid rafts (138), so we asked whether Fas stimulation resulted in rapid palmitoylation of Lck. Fas stimulation resulted in a rapid increase in de novo palmitoylation of Lck detectable within minutes of Fas receptor engagement (18). Unexpectedly, the lipid moiety was removed from Lck almost as quickly, and Lck palmitoylation was almost undetectable by $30 \mathrm{~min}$. These kinetics closely matched the phosphorylation and de-phosphorylation of canonical TCR components, such as Zap-70 and PLC- $\gamma 1$ (18). These findings strongly suggest that the enzymatic mechanisms controlling stimulus-dependent protein palmitoylation and depalmitoylation likely are directly activated by components of the Fas signaling pathway. In the case of Fas signaling, the plasma membrane-localized DHHC21 protein is essential (18). Presumably Fas stimulation rapidly activates DHHC21 and a yet unidentified acyl-protein thioesterase to regulate Lck lipidation 


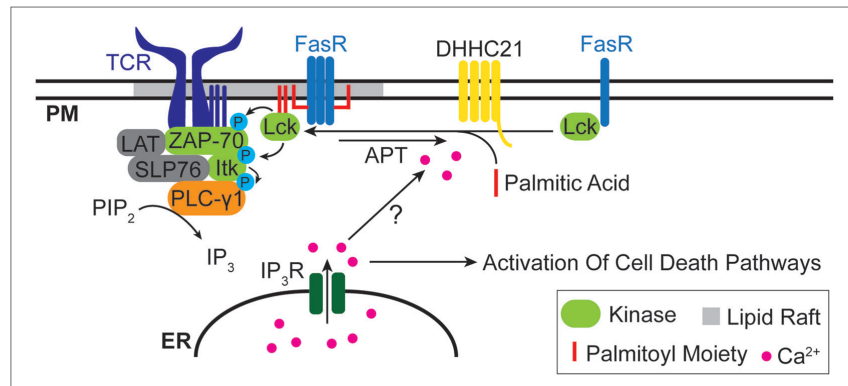

FIGURE 1 | Lipidation and Fas death receptor signaling. The Src kinase Lck is rapidly palmitoylated upon Fas stimulation and partitioned into lipid rafts, where it interacts with the T cell receptor (TCR) complex and leads to downstream apoptotic calcium release. The plasma membrane-localized palmitoyl acyltransferases $\mathrm{DHHC} 21$ is essential for Lck palmitoylation. The identity of the depalmitoylating enzyme(s) for Lck is unclear.

levels (Figure 1). How the activation of these enzymes occurs is unknown, but could possibly be regulated either directly or indirectly by calcium ions.

In addition to palmitoylation, there has been intense interest in how other lipid modifications are coupled to the cell signaling/cell death machinery. As mentioned above myristoylation of Src kinases regulates their localization to the plasma membrane, which would have implications for coupling to the apoptotic calcium release machinery. The Src-related kinase c-Abl is recruited to membranes via a myristoyl/phosphotyrosine switch $(139,140)$. The c-Abl kinase sequesters the myristoyl group in a hydrophobic pocket, a conformation which is essential for autoinhibition of the enzyme (140). Binding of phosphotyrosine ligands to the $\mathrm{SH} 2$ domain causes a conformational change which results in displacement of the myristoyl group from the pocket, activation of the kinase, and membrane localization. Thus, even though myristoylation is a stable modification, the regulated exposure of the lipid group allows stimulus-dependent regulation of the kinase. During cell death induced by calcium store depletion and subsequent ER stress, c-Abl translocates to mitochondrial membranes to stimulate cytochrome $c$ release (141). It is important to note that the myristoyl switch is not conserved in all Src-related kinases. For example, Lck has bulky residues which occlude the myristoyl binding pocket, and combined with biochemical evidence $(142,143)$, suggest that a myristoyl switch does not operate in Lck.

Prenylation is a prominent modification of many disease relevant proteins. Small GTPases, such as Rab, Rho, and Ras, are arguably the best studied prenylated proteins; however, as mentioned above, many other proteins have also been shown to be prenylated including chaperones, kinases, enzymes, and receptors (110). How prenylation is linked to apoptotic calcium release has mostly been elucidated by studying the effects of HMG-CoA reductase inhibitors (more commonly known as statins). Many studies have shown that statins induce cell death of multiple cell types, and it is generally assumed to be due to decreased prenylation of GTPases such as Ras and Rho (144-147). We showed that simvastatin was a potent inducer of calcium-dependent apoptosis in human leiomyoma cells (148). The mechanism included inhibition of ERK signaling downstream of Ras and activation of plasma membrane L-type calcium channels via a still unknown mechanism. We were able to extend these finding to xenograft models (149) and showed in a nested case-control study that statin users had a lower risk of uterine fibroid tumors and related symptoms (150). Statins may also be effective for inhibiting the proliferation of many other tumor types including breast (151), ovarian (152), colon (153), and other cancers.

\section{LIPIDATION AND CALCIUM-DEPENDENT TUMOR PROGRESSION}

In addition to regulating cell death signaling, calcium is also a key factor in proliferative and pro-metastatic signaling. In many types of cancer, alterations in expression, localization, and functions of calcium pumps and channels are observed, resulting in ectopic calcium flux across the plasma membrane or intracellular organelles (154). Studies in prostate (155-157), colon (158), breast $(159,160)$, and ovarian (161) cancers demonstrated that multiple transient receptor potential (TRP) channels, a family of calcium permeable ion channels, are overexpressed and regulate proliferation in primary tumors. Additionally, TRP channels contribute to tumor cell migration by generating localized calcium signals that guide the direction of movement toward growth factors $(162,163)$. Another calcium-dependent pathway related to metastasis is the store-operated calcium entry (SOCE) mediated by ER calcium sensor stromal interaction molecule 1 and the plasma membrane calcium channel ORAI1. This pathway has been extensively studied in breast cancer, where it accelerates the turnover rate of focal adhesions by reorganizing the actin cytoskeleton in a Ras and Rac-dependent manner (164). The SOCE pathway is activated by G-protein coupled receptormediated activation of the phospholipase $\mathrm{C}-\mathrm{IP}_{3} \mathrm{R}$ pathway, which results in calcium release from ER stores and contributes to metastasis by promoting actin assembly $(165,166)$.

Many proteins involved in the calcium-dependent proliferative and pro-metastatic pathways are regulated by lipidation (Figure 2). The Wnt signaling pathway is an extensively studied mediator of tumor progression. Immature Wnt proteins (with the exception of $\mathrm{WntD}$ ) require $\mathrm{N}$-glycosylation and lipidation, specifically palmitate/palmitoleic acylation on conserved C77/ C93 and S209/S24 residues for proper secretion and subsequent recognition by Frizzled (Fzd) receptors (167-169). In addition to canonical $\beta$-catenin-dependent Wnt signaling, Wnt ligands such as Wnt5a bind Fzd receptors and activate PLC via $\mathrm{G}$-proteins leading to $\mathrm{IP}_{3} \mathrm{R}$-mediated increase in cytosolic calcium levels (170). Activation of the non-canonical Wnt/ $\mathrm{Ca}^{2+}$ pathway has been implicated in multiple cancer types, including melanoma where it promotes invasion by initiating epithelialto-mesenchymal transition $(171,172)$. Increasing in vitro data indicate that Wnt lipidation at the two sites is differentially regulated and activates distinct canonical versus non-canonical pathways (173), but their exact functions in different types of cancers remain unclear. Therefore, further characterization of Wnt lipidation and the mechanisms through which they regulate calcium-dependent proliferation and migration is necessary.

Another class of lipidated proteins that are involved in calcium-mediated cancer progression is the small GTPases, 


\begin{tabular}{|c|c|c|}
\hline Lipid Structure & Effects on proteins & Effects on downstream signaling in cancer \\
\hline GPI anchor & $\begin{array}{l}\text { Plasma membrane } \\
\text { tethering } \\
\text { Incorporation into specific } \\
\text { membrane domains } \\
\text { Protein-protein interaction }\end{array}$ & $\begin{array}{l}\text { Increase cell division in bladder }{ }^{197} \text {, } \\
\text { breast }^{198}, \text { colon }^{199,} \text { and other cancers }\end{array}$ \\
\hline Cholesterylat & $\begin{array}{l}\text { Hedgehog signaling } \\
\text { activation }\end{array}$ & $\begin{array}{l}\text { Facilitate tumorigenesis and cancer } \\
\text { growth in prostate } \\
\text { bladder } \text { breast }^{201} \\
\text { blad }^{202} \text { and other cancers }\end{array}$ \\
\hline Myristoylation & $\begin{array}{l}\text { Membrane localization } \\
\text { Autoinhibition }\end{array}$ & $\begin{array}{l}\text { Carcinogenesis in breast }{ }^{203} \text {, lung }{ }^{204} \text {, } \\
\text { and other cancers }\end{array}$ \\
\hline Palmitoylation & $\begin{array}{l}\text { Plasma membrane } \\
\text { localization } \\
\text { Partitioning into lipid rafts } \\
\text { Protein maturation/quality } \\
\text { control }\end{array}$ & $\begin{array}{l}\text { Promote proliferation and invasion in } \\
\text { melanoma }{ }^{170} \text {, intestinal }{ }^{205} \text {, and other } \\
\text { cancers }\end{array}$ \\
\hline Farnesylation & $\begin{array}{l}\text { Membrane localization } \\
\text { Conformational change } \\
\text { Protein-protein interaction }\end{array}$ & $\begin{array}{l}\text { Promote cell growth, survival and } \\
\text { metastasis in lung } 206, \text { myeloid leukemia }{ }^{207}, \\
\text { pancreatic }\end{array}$ \\
\hline Geranylgerany & $\begin{array}{l}\text { Membrane localization } \\
\text { Protein-protein interaction }\end{array}$ & $\begin{array}{l}\text { Facilitate cell proliferation and migration } \\
\text { in lymphoma }{ }^{177} \text {, leukemia } \\
\text { and other cancers }\end{array}$ \\
\hline
\end{tabular}

FIGURE 2 | Lipidation structures and effects on downstream signaling in cancer. Increase GPI transamidase activity leads to increased cell proliferation in bladder (174), breast (175), and colon (176) cancers. Elevated hedgehog signaling is linked to sporadic tumorigenesis in prostate (177), breast (178), and bladder (179) cancers. Increased NMT activity and myristoylated Src kinases are linked to increased cell proliferation in breast (180), lung (181), and other cancers. Palmitoylation of signaling proteins in multiple pathways are linked to proliferation and invasion in melanoma (171), intestinal (182), and other cancers. Targeting farnesylation of Ras proteins slows down tumor progression in lung (183), leukemia (184), pancreatic (185), and other cancers. Geranylgeranylation of small GTPases facilitate cell proliferation and migration in lymphoma (186), leukemia (187), and other cancers.

including Ras, Rho and Rac, which are known regulators of the calcium-dependent cytoskeletal rearrangement $(164,188)$. All three major mammalian isoforms of Ras (H-Ras, N-Ras and K-Ras4B) are farnesylated at the C-terminus (189). Ras farnesylation is required for membrane localization and activation of downstream pathways to induce tumorigenesis (190). Additionally, H-Ras and N-Ras are palmitoylated in the Golgi and subsequently localized to the plasma membrane, where it can be depalmitoylated and cycled back to the Golgi, leading to spatial and temporal control of Ras signaling (191). Rho and Rac are geranylgeranylated near the C-terminus and blocking geranylgeranylation leads to reduced cancer cell proliferation and migration $(186,192)$.

\section{LIPIDATION AS A DRUG TARGET IN CANCER}

Many oncogenic proteins require lipidation for proper function. Indeed, Ras is one of the most commonly mutated proteins in cancer (193). As such, the enzymes that mediate these modifications are excellent targets for drug development. Inhibitors of prenylation enzymes GGTase 1 and FTase are being developed to treat cancer. The GGTase 1 inhibitor PTX-200 (GGTI-2418) is being tested in clinical trials by Prescient Therapeutics for breast cancer and multiple myeloma; however, the Phase I trial data has not been published. Many more drugs have been developed which target FTases. There have been several clinical trials conducted with FTase inhibitors, such as lonafarnib, and tipifarnib (194); however, the results have been mostly disappointing (195). Interestingly, positive clinical responses were not correlated to Ras mutation status, suggesting that the drugs target other pathways or substrates (196). Drugs targeting the post-prenylation processing enzymes RCE1 and ICMT are in pre-clinical development (195, 197-199).

As mentioned above, many oncogenic proteins require palmitoylation for proper function, including Ras and Src proteins. There are very few pharmacological tools to target the DHHC enzymes; however, the irreversible lipid-based inhibitor 2-bromopalmitate (200) and several non-lipid reversible 
inhibitors (201) are widely used as research tools to probe the role of palmitoylation in biological processes. There are no drugs sufficiently well developed to initiate clinical trials, most likely due to the fact that selective DHHC enzyme inhibitors would likely need to be developed. As there are so many enzymes with potentially overlapping substrates, this seems to be a very daunting task. However, new targeted screening strategies for therapeutically relevant substrates, such as Ras, show great promise (202).

As mentioned above, statins are potent inhibitors of the mevalonate pathway and thus may be an attractive target for further development as anti-cancer agents. Indeed, several prospective and retrospective studies have shown that statins have activity against a wide variety of cancers (203-209). There are a multitude of prospective clinical trials currently underway to evaluate the potential of statins as anti-cancer therapeutics. Interestingly, the mechanism of action for inhibiting cancer progression by statins may reflect targeting of multiple pathways,

\section{REFERENCES}

1. Schweizer M, Richter C. Peroxynitrite stimulates the pyridine nucleotide-linked $\mathrm{Ca} 2+$ release from intact rat liver mitochondria. Biochemistry (1996) 35(14):4524-8. doi:10.1021/bi952708+

2. Kidd JF, Pilkington MF, Schell MJ, Fogarty KE, Skepper JN, Taylor CW, et al. Paclitaxel affects cytosolic calcium signals by opening the mitochondrial permeability transition pore. J Biol Chem (2002) 277(8):6504-10. doi:10.1074/ jbc.M106802200

3. Pinton P, Ferrari D, Magalhães P, Schulze-Osthoff K, Di Virgilio F, Pozzan T, et al. Reduced loading of intracellular $\mathrm{Ca}(2+)$ stores and downregulation of capacitative $\mathrm{Ca}(2+)$ influx in Bcl-2-overexpressing cells. J Cell Biol (2000) 148(5):857-62. doi:10.1083/jcb.148.5.857

4. Foyouzi-Youssefi R, Arnaudeau S, Borner C, Kelley WL, Tschopp J, Lew DP, et al. Bcl-2 decreases the free $\mathrm{Ca} 2+$ concentration within the endoplasmic reticulum. Proc Natl Acad Sci U S A (2000) 97(11):5723-8. doi:10.1073/ pnas.97.11.5723

5. Chen R, Valencia I, Zhong F, McColl KS, Roderick HL, Bootman MD, et al. $\mathrm{Bcl}-2$ functionally interacts with inositol 1,4,5-trisphosphate receptors to regulate calcium release from the ER in response to inositol 1,4,5-trisphosphate. J Cell Biol (2004) 166(2):193-203. doi:10.1083/jcb.200309146

6. Rong YP, Aromolaran AS, Bultynck G, Zhong F, Li X, McColl K, et al. Targeting Bcl-2-IP3 receptor interaction to reverse Bcl-2's inhibition of apoptotic calcium signals. Mol Cell (2008) 31(2):255-65. doi:10.1016/j. molcel.2008.06.014

7. Scorrano L, Oakes SA, Opferman JT, Cheng EH, Sorcinelli MD, Pozzan T, et al. BAX and BAK regulation of endoplasmic reticulum Ca2+: a control point for apoptosis. Science (2003) 300(5616):135-9. doi:10.1126/science. 1081208

8. Oakes SA, Scorrano L, Opferman JT, Bassik MC, Nishino M, Pozzan T, et al. Proapoptotic BAX and BAK regulate the type 1 inositol trisphosphate receptor and calcium leak from the endoplasmic reticulum. Proc Natl Acad Sci U S A (2005) 102(1):105-10. doi:10.1073/pnas.0408352102

9. Vervliet T, Parys JB, Bultynck G. Bcl-2 proteins and calcium signaling: complexity beneath the surface. Oncogene (2016) 35(39):5079-92. doi:10.1038/ onc. 2016.31

10. Dremina ES, Sharov VS, Kumar K, Zaidi A, Michaelis EK, Schöneich C. Antiapoptotic protein Bcl-2 interacts with and destabilizes the sarcoplasmic/ endoplasmic reticulum Ca2+-ATPase (SERCA). Biochem J (2004) 383(Pt 2): 361-70. doi:10.1042/BJ20040187

11. Ferdek PE, Gerasimenko JV, Peng S, Tepikin AV, Petersen OH, Gerasimenko OV. A novel role for Bcl-2 in regulation of cellular calcium extrusion. Curr Biol (2012) 22(13):1241-6. doi:10.1016/j.cub.2012.05.002 including prenylation of oncogenic proteins and the production of hormones synthesized from cholesterol such as estrogen and testosterone which can drive tumor growth. Statins are one of the most widely prescribed drugs in the world with excellent safety and tolerability profiles (210). If statins prove to be efficacious as a cancer preventative or treatment, this would have the potential to revolutionize cancer care and survival.

\section{AUTHOR CONTRIBUTIONS}

The content of this review was conceived by DB and written with equal effort by JC and DB.

\section{FUNDING}

This work is supported by National Institutes of Health (NIH) grant R01GM081685 (DB).

12. Orrenius S, Zhivotovsky B, Nicotera P. Regulation of cell death: the calcium-apoptosis link. Nat Rev Mol Cell Biol (2003) 4(7):552-65 doi:10.1038/nrm1150

13. Boldin MP, Goncharov TM, Goltsev YV, Wallach D. Involvement of $\mathrm{MACH}$, a novel MORT1/FADD-interacting protease, in Fas/APO-1- and TNF receptor-induced cell death. Cell (1996) 85(6):803-15. doi:10.1016/ S0092-8674(00)81265-9

14. Muzio M, Chinnaiyan AM, Kischkel FC, O’Reourke K, Shevchenko A, $\mathrm{Ni}$ J, et al. FLICE, a novel FADD-homologous ICE/CED-3-like protease, is recruited to the CD95 (Fas/APO-1) death-inducing signaling complex. Cell (1996) 85(6):817-27. doi:10.1016/S0092-8674(00)81266-0

15. Fernandes-Alnemri T, Armstrong RC, Krebs J, Srinivasula SM, Wang L, Bullrich F, et al. In vitro activation of CPP32 and Mch3 by Mch4, a novel human apoptotic cysteine protease containing two FADD-like domains. Proc Natl Acad Sci U S A (1996) 93(15):7464-9. doi:10.1073/pnas.93.15.7464

16. Scaffidi C, Fulda S, Srinivasan A, Friesen C, Li F, Tomaselli KJ, et al. Two CD95 (APO-1/Fas) signaling pathways. EMBO J (1998) 17(6):1675-87. doi:10.1093/emboj/17.6.1675

17. Barnhart BC, Alappat EC, Peter ME. The CD95 type I/type II model. Semin Immunol (2003) 15(3):185-93. doi:10.1016/S1044-5323(03)00031-9

18. Akimzhanov AM, Boehning D. Rapid and transient palmitoylation of the tyrosine kinase Lck mediates Fas signaling. Proc Natl Acad Sci U S A (2015) 112(38):11876-80. doi:10.1073/pnas.1509929112

19. Akimzhanov AM, Wang X, Sun J, Boehning D. T-cell receptor complex is essential for Fas signal transduction. Proc Natl Acad Sci U S A (2010) 107(34):15105-10. doi:10.1073/pnas.1005419107

20. Steinmann C, Landsverk ML, Barral JM, Boehning D. Requirement of inositol 1,4,5-trisphosphate receptors for tumor-mediated lymphocyte apoptosis. J Biol Chem (2008) 283(20):13506-9. doi:10.1074/jbc.C800029200

21. Wozniak AL, Wang X, Stieren ES, Scarbrough SG, Elferink CJ, Boehning D. Requirement of biphasic calcium release from the endoplasmic reticulum for Fas-mediated apoptosis. J Cell Biol (2006) 175(5):709-14. doi:10.1083/ jcb.200608035

22. Nadolski MJ, Linder ME. Protein lipidation. FEBS J (2007) 274(20):5202-10. doi:10.1111/j.1742-4658.2007.06056.x

23. Ferguson MA, Low MG, Cross GA. Glycosyl-sn-1,2dimyristylphosphatidylinositol is covalently linked to Trypanosoma brucei variant surface glycoprotein. J Biol Chem (1985) 260(27):14547-55.

24. Ferguson MA, Homans SW, Dwek RA, Rademacher TW. The glycosylphosphatidylinositol membrane anchor of Trypanosoma brucei variant surface glycoprotein. Biochem Soc Trans (1988) 16(3):265-8. doi:10.1042/bst0160265

25. Ferguson MA, Williams AF. Cell-surface anchoring of proteins via glycosyl-phosphatidylinositol structures. Annu Rev Biochem (1988) 57:285-320. 
26. Thomas JR, Dwek RA, Rademacher TW. Structure, biosynthesis, and function of glycosylphosphatidylinositols. Biochemistry (1990) 29(23):5413-22. doi:10.1021/bi00475a001

27. Englund PT. The structure and biosynthesis of glycosyl phosphatidylinositol protein anchors. Annu Rev Biochem (1993) 62:121-38. doi:10.1146/annurev. bi.62.070193.001005

28. Paulick MG, Bertozzi CR. The glycosylphosphatidylinositol anchor: a complex membrane-anchoring structure for proteins. Biochemistry (2008) 47(27):6991-7000. doi:10.1021/bi8006324

29. Caras IW, Weddell GN, Davitz MA, Nussenzweig V, Martin DW Jr. Signal for attachment of a phospholipid membrane anchor in decay accelerating factor. Science (1987) 238(4831):1280-3. doi:10.1126/science.2446389

30. Takeda J, Kinoshita T. GPI-anchor biosynthesis. Trends Biochem Sci (1995) 20(9):367-71. doi:10.1016/S0968-0004(00)89078-7

31. Chatterjee S, Mayor S. The GPI-anchor and protein sorting. Cell Mol Life Sci (2001) 58(14):1969-87. doi:10.1007/PL00000831

32. Ferguson MAJ, Kinoshita T, Hart GW. Glycosylphosphatidylinositol anchors. In: Varki A, Cummings RD, Esko JD, Freeze HH, Stanley P, Bertozzi CR, et al., editors. Essentials of Glycobiology. NY: Cold Spring Harbor (2009).

33. Fujita M, Kinoshita T. Structural remodeling of GPI anchors during biosynthesis and after attachment to proteins. FEBS Lett (2010) 584(9):1670-7. doi:10.1016/j.febslet.2009.10.079

34. Nusslein-Volhard C, Wieschaus E. Mutations affecting segment number and polarity in Drosophila. Nature (1980) 287(5785):795-801.

35. Porter JA, Young KE, Beachy PA. Cholesterol modification of hedgehog signaling proteins in animal development. Science (1996) 274(5285):255-9. doi:10.1126/science.274.5285.255

36. Lee JJ, Ekker SC, von Kessler DP, Porter JA, Sun BI, Beachy PA. Autoproteolysis in hedgehog protein biogenesis. Science (1994) 266(5190):1528-37. doi:10.1126/ science.7985023

37. Porter JA, von Kessler DP, Ekker SC, Young KE, Lee JJ, Moses K, et al. The product of hedgehog autoproteolytic cleavage active in local and long-range signalling. Nature (1995) 374(6520):363-6. doi:10.1038/374363a0

38. Fan CM, Porter JA, Chiang C, Chang DT, Beachy PA, Tessier-Lavigne M. Long-range sclerotome induction by sonic hedgehog: direct role of the amino-terminal cleavage product and modulation by the cyclic AMP signaling pathway. Cell (1995) 81(3):457-65. doi:10.1016/0092-8674(95)90398-4

39. Heal WP, Jovanovic B, Bessin S, Wright MH, Magee AI, Tate EW. Bioorthogonal chemical tagging of protein cholesterylation in living cells. Chem Commun (Camb) (2011) 47(14):4081-3. doi:10.1039/c0cc04710d

40. Towler DA, Eubanks SR, Towery DS, Adams SP, Glaser L. Amino-terminal processing of proteins by N-myristoylation. Substrate specificity of N-myristoyl transferase. J Biol Chem (1987) 262(3):1030-6.

41. Carr SA, Biemann K, Shoji S, Parmelee DC, Titani K. n-Tetradecanoyl is the NH2-terminal blocking group of the catalytic subunit of cyclic AMPdependent protein kinase from bovine cardiac muscle. Proc Natl Acad Sci US A (1982) 79(20):6128-31. doi:10.1073/pnas.79.20.6128

42. Aitken A, Cohen P, Santikarn S, Williams DH, Calder AG, Smith A, et al. Identification of the NH2-terminal blocking group of calcineurin B as myristic acid. FEBS Lett (1982) 150(2):314-8. doi:10.1016/0014-5793(82) 80759-X

43. Buss JE, Sefton BM. Myristic acid, a rare fatty acid, is the lipid attached to the transforming protein of Rous sarcoma virus and its cellular homolog. J Virol (1985) 53(1):7-12.

44. Linder ME, Burr JG. Nonmyristoylated p60v-src fails to phosphorylate proteins of $115-120 \mathrm{kDa}$ in chicken embryo fibroblasts. Proc Natl Acad Sci U S A (1988) 85(8):2608-12. doi:10.1073/pnas.85.8.2608

45. Buss JE, Mumby SM, Casey PJ, Gilman AG, Sefton BM. Myristoylated alpha subunits of guanine nucleotide-binding regulatory proteins. Proc Natl Acad Sci U S A (1987) 84(21):7493-7. doi:10.1073/pnas.84.21.7493

46. Mumby SM, Heukeroth RO, Gordon JI, Gilman AG. G-protein alpha-subunit expression, myristoylation, and membrane association in COS cells. Proc Natl Acad Sci U S A (1990) 87(2):728-32. doi:10.1073/pnas.87.2.728

47. Maurer-Stroh S, Eisenhaber B, Eisenhaber F. N-terminal N-myristoylation of proteins: prediction of substrate proteins from amino acid sequence. $J \mathrm{Mol}$ Biol (2002) 317(4):541-57. doi:10.1006/jmbi.2002.5426

48. Wilcox C, Hu JS, Olson EN. Acylation of proteins with myristic acid occurs cotranslationally. Science (1987) 238(4831):1275-8. doi:10.1126/ science. 3685978
49. Peitzsch RM, McLaughlin S. Binding of acylated peptides and fatty acids to phospholipid vesicles: pertinence to myristoylated proteins. Biochemistry (1993) 32(39):10436-43. doi:10.1021/bi00090a020

50. Ames JB, Tanaka T, Stryer L, Ikura M. Portrait of a myristoyl switch protein. Curr Opin Struct Biol (1996) 6(4):432-8. doi:10.1016/S0959-440X(96) 80106-0

51. Seykora JT, Myat MM, Allen LA, Ravetch JV, Aderem A. Molecular determinants of the myristoyl-electrostatic switch of MARCKS. J Biol Chem (1996) 271(31):18797-802. doi:10.1074/jbc.271.31.18797

52. Zha J, Weiler S, Oh KJ, Wei MC, Korsmeyer SJ. Posttranslational $\mathrm{N}$-myristoylation of BID as a molecular switch for targeting mitochondria and apoptosis. Science (2000) 290(5497):1761-5. doi:10.1126/ science.290.5497.1761

53. Utsumi T, Sakurai N, Nakano K, Ishisaka R. C-terminal $15 \mathrm{kDa}$ fragment of cytoskeletal actin is posttranslationally N-myristoylated upon caspase-mediated cleavage and targeted to mitochondria. FEBS Lett (2003) 539(1-3):37-44. doi:10.1016/S0014-5793(03)00180-7

54. Sakurai N, Utsumi T. Posttranslational N-myristoylation is required for the anti-apoptotic activity of human tGelsolin, the C-terminal caspase cleavage product of human gelsolin. J Biol Chem (2006) 281(20):14288-95. doi:10.1074/jbc.M510338200

55. Martin DD, Vilas GL, Prescher JA, Rajaiah G, Falck JR, Bertozzi CR, et al. Rapid detection, discovery, and identification of post-translationally myristoylated proteins during apoptosis using a bio-orthogonal azidomyristate analog. FASEB J (2008) 22(3):797-806. doi:10.1096/fj.07-9198com

56. Liang X, Lu Y, Neubert TA, Resh MD. Mass spectrometric analysis of GAP43/neuromodulin reveals the presence of a variety of fatty acylated species. J Biol Chem (2002) 277(36):33032-40. doi:10.1074/jbc.M204607200

57. Takada R, Satomi Y, Kurata T, Ueno N, Norioka S, Kondoh H, et al Monounsaturated fatty acid modification of Wnt protein: its role in Wnt secretion. Dev Cell (2006) 11(6):791-801. doi:10.1016/j.devcel.2006.10.003

58. Magee AI, Koyama AH, Malfer C, Wen D, Schlesinger MJ. Release of fatty acids from virus glycoproteins by hydroxylamine. Biochim Biophys Acta (1984) 798(2):156-66. doi:10.1016/0304-4165(84)90298-8

59. Kaufman JF, Krangel MS, Strominger JL. Cysteines in the transmembrane region of major histocompatibility complex antigens are fatty acylated via thioester bonds. J Biol Chem (1984) 259(11):7230-8.

60. Xue Y, Chen H, Jin C, Sun Z, Yao X. NBA-Palm: prediction of palmitoylation site implemented in Naive Bayes algorithm. BMC Bioinformatics (2006) 7:458. doi:10.1186/1471-2105-7-458

61. Ren J, Wen L, Gao X, Jin C, Xue Y, Yao X. CSS-Palm 2.0: an updated software for palmitoylation sites prediction. Protein Eng Des Sel (2008) 21(11):639-44. doi:10.1093/protein/gzn039

62. Li YX, Shao YH, Deng NY. Improved prediction of palmitoylation sites using PWMs and SVM. Protein Pept Lett (2011) 18(2):186-93. doi:10.2174/092986611794475084

63. Rocks O, Gerauer M, Vartak N, Koch S, Huang ZP, Pechlivanis M, et al. The palmitoylation machinery is a spatially organizing system for peripheral membrane proteins. Cell (2010) 141(3):458-71. doi:10.1016/j. cell.2010.04.007

64. O'Brien PJ, Zatz M. Acylation of bovine rhodopsin by [3H]palmitic acid. J Biol Chem (1984) 259(8):5054-7.

65. Schmidt JW, Catterall WA. Palmitylation, sulfation, and glycosylation of the alpha subunit of the sodium channel. Role of post-translational modifications in channel assembly. J Biol Chem (1987) 262(28):13713-23.

66. O’Dowd BF, Hnatowich M, Caron MG, Lefkowitz RJ, Bouvier M. Palmitoylation of the human beta 2-adrenergic receptor. Mutation of Cys341 in the carboxyl tail leads to an uncoupled nonpalmitoylated form of the receptor. J Biol Chem (1989) 264(13):7564-9.

67. Hawtin SR, Tobin AB, Patel S, Wheatley M. Palmitoylation of the vasopressin V1a receptor reveals different conformational requirements for signaling, agonist-induced receptor phosphorylation, and sequestration. J Biol Chem (2001) 276(41):38139-46. doi:10.1074/jbc.M106142200

68. Zhang L, Foster K, Li Q, Martens JR. S-acylation regulates Kv1.5 channel surface expression. Am JPhysiol Cell Physiol (2007) 293(1):C152-61. doi:10.1152/ajpheart.00268.2006

69. Hayashi T, Rumbaugh G, Huganir RL. Differential regulation of AMPA receptor subunit trafficking by palmitoylation of two distinct sites. Neuron (2005) 47(5):709-23. doi:10.1016/j.neuron.2005.06.035 
70. Zheng H, Chu J, Qiu Y, Loh HH, Law PY. Agonist-selective signaling is determined by the receptor location within the membrane domains. Proc Natl Acad Sci U S A (2008) 105(27):9421-6. doi:10.1073/pnas.0802253105

71. Gonnord P, Delarasse C, Auger R, Benihoud K, Prigent M, Cuif MH, et al. Palmitoylation of the P2X7 receptor, an ATP-gated channel, controls its expression and association with lipid rafts. FASEB J (2009) 23(3):795-805. doi:10.1096/fj.08-114637

72. Hayashi T, Thomas GM, Huganir RL. Dual palmitoylation of NR2 subunits regulates NMDA receptor trafficking. Neuron (2009) 64(2):213-26. doi:10.1016/j.neuron.2009.08.017

73. Kamiya Y, Sakurai A, Tamura S, Takahashi N. Structure of rhodotorucine A, a novel lipopeptide, inducing mating tube formation in Rhodosporidium toruloides. Biochem Biophys Res Commun (1978) 83(3):1077-83. doi:10.1016/0006-291X(78)91505-X

74. Farnsworth CC, Gelb MH, Glomset JA. Identification of geranylgeranyl-modified proteins in HeLa cells. Science (1990) 247(4940):320-2. doi:10.1126/science. 2296721

75. Hancock JF, Magee AI, Childs JE, Marshall CJ. All ras proteins are polyisoprenylated but only some are palmitoylated. Cell (1989) 57(7):1167-77. doi:10.1016/0092-8674(89)90054-8

76. Casey PJ, Solski PA, Der CJ, Buss JE. p21ras is modified by a farnesyl isoprenoid. Proc Natl Acad Sci U S A (1989) 86(21):8323-7. doi:10.1073/ pnas.86.21.8323

77. Hoffman GR, Nassar N, Cerione RA. Structure of the Rho family GTP-binding protein $\mathrm{Cdc} 42$ in complex with the multifunctional regulator RhoGDI. Cell (2000) 100(3):345-56. doi:10.1016/S0092-8674(00)80670-4

78. Berg TJ, Gastonguay AJ, Lorimer EL, Kuhnmuench JR, Li R, Fields AP, et al. Splice variants of SmgGDS control small GTPase prenylation and membrane localization. J Biol Chem (2010) 285(46):35255-66. doi:10.1074/ jbc.M110.129916

79. Benghezal M, Lipke PN, Conzelmann A. Identification of six complementation classes involved in the biosynthesis of glycosylphosphatidylinositol anchors in Saccharomyces cerevisiae. JCell Biol (1995) 130(6):1333-44. doi:10.1083/jcb.130.6.1333

80. Hamburger D, Egerton M, Riezman $H$. Yeast Gaalp is required for attachment of a completed GPI anchor onto proteins. J Cell Biol (1995) 129(3):629-39. doi:10.1083/jcb.129.3.629

81. Benghezal M, Benachour A, Rusconi S, Aebi M, Conzelmann A. Yeast Gpi8p is essential for GPI anchor attachment onto proteins. EMBO J (1996) 15(23):6575-83.

82. Fraering P, Imhof I, Meyer U, Strub JM, van Dorsselaer A, Vionnet C, et al. The GPI transamidase complex of Saccharomyces cerevisiae contains Gaalp, Gpi8p, and Gpi16p. Mol Biol Cell (2001) 12(10):3295-306. doi:10.1091/mbc.12.10.3295

83. Chen R, Anderson V, Hiroi Y, Medof ME. Proprotein interaction with the GPI transamidase. J Cell Biochem (2003) 88(5):1025-37. doi:10.1002/jcb.10439

84. Duronio RJ, Towler DA, Heuckeroth RO, Gordon JI. Disruption of the yeast N-myristoyl transferase gene causes recessive lethality. Science (1989) 243(4892):796-800. doi:10.1126/science.2644694

85. Ntwasa M, Egerton M, Gay NJ. Sequence and expression of Drosophila myristoyl-CoA:protein N-myristoyl transferase: evidence for proteolytic processing and membrane localisation. JCell Sci (1997) 110(Pt 2): $149-56$.

86. Giang DK, Cravatt BF. A second mammalian N-myristoyltransferase. J Biol Chem (1998) 273(12):6595-8. doi:10.1074/jbc.273.12.6595

87. Rudnick DA, McWherter CA, Rocque WJ, Lennon PJ, Getman DP, Gordon JI. Kinetic and structural evidence for a sequential ordered Bi Bi mechanism of catalysis by Saccharomyces cerevisiae myristoyl-CoA:protein N-myristoyltransferase. J Biol Chem (1991) 266(15):9732-9.

88. Boutin JA, Ferry G, Ernould A, Maes P, Remond G, Vincent M. MyristoylCoA: protein $\mathrm{N}$-myristoyltransferase activity in cancer cells. Purification and characterization of a cytosolic isoform from the murine leukemia cell line L1210. Eur J Biochem (1993) 214(3):853-67.

89. Mcllhinney RA, McGlone K, Willis AC. Purification and partial sequencing of myristoyl-CoA:protein N-myristoyltransferase from bovine brain. Biochem J (1993) 290(Pt 2):405-10. doi:10.1042/bj2900405

90. Raju RV, Kalra J, Sharma RK. Purification and properties of bovine spleen N-myristoyl-CoA protein:N-myristoyltransferase. J Biol Chem (1994) 269(16):12080-3.
91. Mcllhinney RA, McGlone K. Immunocytochemical characterization and subcellular localization of human myristoyl-CoA: protein $\mathrm{N}$-myristoyltransferase in HeLa cells. Exp Cell Res (1996) 223(2):348-56. doi:10.1006/excr.1996.0090

92. van der Vusse GJ, van Bilsen M, Glatz JF, Hasselbaink DM, Luiken JJ. Critical steps in cellular fatty acid uptake and utilization. Mol Cell Biochem (2002) 239(1-2):9-15. doi:10.1023/A:1020538119691

93. Colombo S, Longhi R, Alcaro S, Ortuso F, Sprocati T, Flora A, et al. $\mathrm{N}$-myristoylation determines dual targeting of mammalian NADHcytochrome b5 reductase to ER and mitochondrial outer membranes by a mechanism of kinetic partitioning. JCell Biol (2005) 168(5):735-45. doi:10.1083/jcb.200407082

94. Selvakumar P, Lakshmikuttyamma A, Shrivastav A, Das SB, Dimmock JR, Sharma RK. Potential role of N-myristoyltransferase in cancer. Prog Lipid Res (2007) 46(1):1-36. doi:10.1016/j.plipres.2006.05.002

95. Fukata M, Fukata Y, Adesnik H, Nicoll RA, Bredt DS. Identification of PSD-95 palmitoylating enzymes. Neuron (2004) 44(6):987-96. doi:10.1016/j. neuron.2004.12.005

96. Mitchell DA, Vasudevan A, Linder ME, Deschenes RJ. Protein palmitoylation by a family of DHHC protein S-acyltransferases. J Lipid Res (2006) 47(6):1118-27. doi:10.1194/jlr.R600007-JLR200

97. Ohno Y, Kihara A, Sano T, Igarashi Y. Intracellular localization and tissue-specific distribution of human and yeast DHHC cysteine-rich domain-containing proteins. Biochim Biophys Acta (2006) 1761(4):474-83. doi:10.1016/j.bbalip.2006.03.010

98. Roth AF, Wan J, Bailey AO, Sun B, Kuchar JA, Green WN, et al. Global analysis of protein palmitoylation in yeast. Cell (2006) 125(5):1003-13. doi:10.1016/j.cell.2006.03.042

99. Fang C, Deng L, Keller CA, Fukata M, Fukata Y, Chen G, et al. GODZmediated palmitoylation of $\mathrm{GABA}(\mathrm{A})$ receptors is required for normal assembly and function of GABAergic inhibitory synapses. J Neurosci (2006) 26(49):12758-68. doi:10.1523/JNEUROSCI.4214-06.2006

100. Fernández-Hernando $\mathrm{C}$, Fukata $\mathrm{M}$, Bernatchez $\mathrm{PN}$, Fukata $\mathrm{Y}$, Lin MI, Bredt DS, et al. Identification of Golgi-localized acyl transferases that palmitoylate and regulate endothelial nitric oxide synthase. J Cell Biol (2006) 174(3):369-77. doi:10.1083/jcb.200601051

101. Camp LA, Hofmann SL. Purification and properties of a palmitoyl-protein thioesterase that cleaves palmitate from H-Ras. J Biol Chem (1993) 268(30):22566-74.

102. Soyombo AA, Hofmann SL. Molecular cloning and expression of palmitoyl-protein thioesterase 2 (PPT2), a homolog of lysosomal palmitoyl-protein thioesterase with a distinct substrate specificity. J Biol Chem (1997) 272(43):27456-63. doi:10.1074/jbc.272.43.27456

103. Duncan JA, Gilman AG. A cytoplasmic acyl-protein thioesterase that removes palmitate from $\mathrm{G}$ protein alpha subunits and $\mathrm{p} 21$ (RAS).J Biol Chem (1998) 273(25):15830-7. doi:10.1074/jbc.273.25.15830

104. Tomatis VM, Trenchi A, Gomez GA, Daniotti JL. Acyl-protein thioesterase 2 catalyzes the deacylation of peripheral membrane-associated GAP-43. PLoS One (2010) 5(11):e15045. doi:10.1371/journal.pone.0015045

105. Camp LA, Verkruyse LA, Afendis SJ, Slaughter CA, Hofmann SL. Molecular cloning and expression of palmitoyl-protein thioesterase. J Biol Chem (1994) 269(37):23212-9.

106. Yokoi N, Fukata Y, Sekiya A, Murakami T, Kobayashi K, Fukata M. Identification of PSD-95 depalmitoylating enzymes. JNeurosci (2016) 36(24):6431-44. doi:10.1523/JNEUROSCI.0419-16.2016

107. Lin DT, Conibear E. ABHD17 proteins are novel protein depalmitoylases that regulate N-Ras palmitate turnover and subcellular localization. Elife (2015) 4:e11306. doi:10.7554/eLife.11306

108. Gibbs JB. Ras C-terminal processing enzymes - new drug targets? Cell (1991) 65(1):1-4. doi:10.1016/0092-8674(91)90352-Y

109. Yoshida Y, Kawata M, Katayama M, Horiuchi H, Kita Y, Takai Y. A geranylgeranyltransferase for rhoA p21 distinct from the farnesyltransferase for ras p21S. Biochem Biophys Res Commun (1991) 175(2):720-8. doi:10.1016/0006-291X(91)91625-M

110. Maurer-Stroh S, Koranda M, Benetka W, Schneider G, Sirota FL, Eisenhaber F. Towards complete sets of farnesylated and geranylgeranylated proteins. PLoS Comput Biol (2007) 3(4):e66. doi:10.1371/journal.pcbi.0030066

111. Andres DA, Seabra MC, Brown MS, Armstrong SA, Smeland TE, Cremers FP, et al. cDNA cloning of component A of Rab geranylgeranyl transferase and 
demonstration of its role as a Rab escort protein. Cell (1993) 73(6):1091-9. doi:10.1016/0092-8674(93)90639-8

112. Taylor JS, Reid TS, Terry KL, Casey PJ, Beese LS. Structure of mammalian protein geranylgeranyltransferase type-I. EMBO J (2003) 22(22):5963-74. doi:10.1093/emboj/cdg571

113. Hartman HL, Hicks KA, Fierke CA. Peptide specificity of protein prenyltransferases is determined mainly by reactivity rather than binding affinity. Biochemistry (2005) 44(46):15314-24. doi:10.1021/bi0509503

114. Zverina EA, Lamphear CL, Wright EN, Fierke CA. Recent advances in protein prenyltransferases: substrate identification, regulation, and disease interventions. Curr Opin Chem Biol (2012) 16(5-6):544-52. doi:10.1016/j. cbpa.2012.10.015

115. Ahearn IM, Haigis K, Bar-Sagi D, Philips MR. Regulating the regulator: post-translational modification of RAS. Nat Rev Mol Cell Biol (2011) 13(1):39-51. doi:10.1038/nrm3255

116. Rao S, Cunningham D, de Gramont A, Scheithauer W, Smakal M, Humblet Y, et al. Phase III double-blind placebo-controlled study of farnesyl transferase inhibitor R115777 in patients with refractory advanced colorectal cancer. J Clin Oncol (2004) 22(19):3950-7. doi:10.1200/JCO.2004.10.037

117. Hrycyna CA, Sapperstein SK, Clarke S, Michaelis S. The Saccharomyces cerevisiae STE14 gene encodes a methyltransferase that mediates C-terminal methylation of a-factor and RAS proteins. EMBO J (1991) 10(7):1699-709.

118. Boyartchuk VL, Ashby MN, Rine J. Modulation of Ras and a-factor function by carboxyl-terminal proteolysis. Science (1997) 275(5307):1796-800. doi:10.1126/science.275.5307.1796

119. Dai Q, Choy E, Chiu V, Romano J, Slivka SR, Steitz SA, et al. Mammalian prenylcysteine carboxyl methyltransferase is in the endoplasmic reticulum. J Biol Chem (1998) 273(24):15030-4. doi:10.1074/jbc.273.24.15030

120. Orrenius S, Gogvadze V, Zhivotovsky B. Calcium and mitochondria in the regulation of cell death. Biochem Biophys Res Commun (2015) 460(1):72-81. doi:10.1016/j.bbrc.2015.01.137

121. Boehning D, Patterson RL, Sedaghat L, Glebova NO, Kurosaki T, Snyder $\mathrm{SH}$. Cytochrome $\mathrm{c}$ binds to inositol $(1,4,5)$ trisphosphate receptors, amplifying calcium-dependent apoptosis. Nat Cell Biol (2003) 5(12):1051-61. doi:10.1038/ncb1063

122. Garcia MI, Chen JJ, Boehning D. Genetically encoded calcium indicators for studying long-term calcium dynamics during apoptosis. Cell Calcium (2017) 61:44-9. doi:10.1016/j.ceca.2016.12.010

123. Boehning D, van Rossum DB, Patterson RL, Snyder SH. A peptide inhibitor of cytochrome c/inositol 1,4,5-trisphosphate receptor binding blocks intrinsic and extrinsic cell death pathways. Proc Natl Acad Sci U S A (2005) 102(5):1466-71. doi:10.1073/pnas.0409650102

124. Hernandez JL, Davda D, Majmudar JD, Won SJ, Prakash A, Choi AI, et al. Correlated S-palmitoylation profiling of snail-induced epithelial to mesenchymal transition. Mol Biosyst (2016) 12(6):1799-808. doi:10.1039/ c6mb00019c

125. Wan J, Savas JN, Roth AF, Sanders SS, Singaraja RR, Hayden MR, et al. Tracking brain palmitoylation change: predominance of glial change in a mouse model of Huntington's disease. Chem Biol (2013) 20(11):1421-34. doi:10.1016/j.chembiol.2013.09.018

126. Fredericks GJ, Hoffmann FW, Rose AH, Osterheld HJ, Hess FM, Mercier F, et al. Stable expression and function of the inositol 1,4,5-triphosphate receptor requires palmitoylation by a DHHC6/selenoprotein K complex. Proc Natl Acad Sci U S A (2014) 111(46):16478-83. doi:10.1073/pnas.1417176111

127. Lynes EM, Raturi A, Shenkman M, Ortiz Sandoval C, Yap MC, Wu J, et al. Palmitoylation is the switch that assigns calnexin to quality control or ER Ca2+ signaling. J Cell Sci (2013) 126(Pt 17):3893-903. doi:10.1242/ jcs. 125856

128. Hannoush RN, Sun J. The chemical toolbox for monitoring protein fatty acylation and prenylation. Nat Chem Biol (2010) 6(7):498-506. doi:10.1038/ nchembio. 388

129. Greaves J, Munro KR, Davidson SC, Riviere M, Wojno J, Smith TK, et al. Molecular basis of fatty acid selectivity in the zDHHC family of S-acyltransferases revealed by click chemistry. Proc Natl Acad Sci U S A (2017) 114(8):E1365-74. doi:10.1073/pnas.1612254114

130. Mumby SM, Kleuss C, Gilman AG. Receptor regulation of G-protein palmitoylation. Proc Natl Acad Sci U S A (1994) 91(7):2800-4. doi:10.1073/ pnas.91.7.2800
131. Degtyarev MY, Spiegel AM, Jones TL. Increased palmitoylation of the Gs protein alpha subunit after activation by the beta-adrenergic receptor or cholera toxin. J Biol Chem (1993) 268(32):23769-72.

132. Wedegaertner PB, Bourne HR. Activation and depalmitoylation of Gs alpha. Cell (1994) 77(7):1063-70. doi:10.1016/0092-8674(94)90445-6

133. Tsutsumi R, Fukata Y, Fukata M. Discovery of protein-palmitoylating enzymes. Pflugers Arch (2008) 456(6):1199-206. doi:10.1007/s00424-008-0465-x

134. Guardiola-Serrano F, Rossin A, Cahuzac N, Lückerath K, Melzer I, Mailfert S, et al. Palmitoylation of human FasL modulates its cell death-inducing function. Cell Death Dis (2010) 1:e88. doi:10.1038/cddis.2010.62

135. Rossin A, Durivault J, Chakhtoura-Feghali T, Lounnas N, Gagnoux-Palacios L, Hueber AO. Fas palmitoylation by the palmitoyl acyltransferase DHHC7 regulates Fas stability. Cell Death Differ (2015) 22(4):643-53. doi:10.1038/cdd.2014.153

136. Rossin A, Derouet M, Abdel-Sater F, Hueber AO. Palmitoylation of the TRAIL receptor DR4 confers an efficient TRAIL-induced cell death signalling. Biochem J (2009) 419(1):185-92, 2 p following 192. doi:10.1042/BJ20081212

137. Berg V, Rusch M, Vartak N, Jüngst C, Schauss A, Waldmann $H$, et al. miRs-138 and -424 control palmitoylation-dependent CD95-mediated cell death by targeting acyl protein thioesterases 1 and 2 in CLL. Blood (2015) 125(19):2948-57. doi:10.1182/blood-2014-07-586511

138. Gajate C, Mollinedo F. Lipid rafts and raft-mediated supramolecular entities in the regulation of $\mathrm{CD} 95$ death receptor apoptotic signaling. Apoptosis (2015) 20(5):584-606. doi:10.1007/s10495-015-1104-6

139. Hantschel O, Nagar B, Guettler S, Kretzschmar J, Dorey K, Kuriyan J, et al. A myristoyl/phosphotyrosine switch regulates c-Abl. Cell (2003) 112(6):845-57. doi:10.1016/S0092-8674(03)00191-0

140. Nagar B, Hantschel O, Young MA, Scheffzek K, Veach D, Bornmann W, et al. Structural basis for the autoinhibition of c-Abl tyrosine kinase. Cell (2003) 112(6):859-71. doi:10.1016/S0092-8674(03)00194-6

141. Ito Y, Pandey P, Mishra N, Kumar S, Narula N, Kharbanda S, et al. Targeting of the c-Abl tyrosine kinase to mitochondria in endoplasmic reticulum stress-induced apoptosis. Mol Cell Biol (2001) 21(18):6233-42. doi:10.1128/ MCB.21.18.6233-6242.2001

142. Abraham N, Veillette A. Activation of p56lck through mutation of a regulatory carboxy-terminal tyrosine residue requires intact sites of autophosphorylation and myristylation. Mol Cell Biol (1990) 10(10):5197-206. doi:10.1128/MCB.10.10.5197

143. Bijlmakers MJ, Isobe-Nakamura M, Ruddock LJ, Marsh M. Intrinsic signals in the unique domain target p56(lck) to the plasma membrane independently of CD4. J Cell Biol (1997) 137(5):1029-40. doi:10.1083/jcb.137.5.1029

144. Blanco-Colio LM, Villa A, Ortego M, Hernández-Presa MA, Pascual A, Plaza JJ, et al. 3-Hydroxy-3-methyl-glutaryl coenzyme A reductase inhibitors, atorvastatin and simvastatin, induce apoptosis of vascular smooth muscle cells by downregulation of $\mathrm{Bcl}-2$ expression and Rho A prenylation. Atherosclerosis (2002) 161(1):17-26. doi:10.1016/S0021-9150(01)00613-X

145. Matzno S, Yasuda S, Juman S, Yamamoto Y, Nagareya-Ishida N, TazuyaMurayama K, et al. Statin-induced apoptosis linked with membrane farnesylated Ras small G protein depletion, rather than geranylated Rho protein. J Pharm Pharmacol (2005) 57(11):1475-84. doi:10.1211/jpp.57.11.0014

146. Brinkkoetter PT, Gottmann U, Schulte J, van der Woude FJ, Braun C, Yard BA. Atorvastatin interferes with activation of human CD4(+) T cells via inhibition of small guanosine triphosphatase (GTPase) activity and caspase-independent apoptosis. Clin Exp Immunol (2006) 146(3):524-32. doi:10.1111/j.1365-2249.2006.03217.x

147. Kah J, Wüstenberg A, Keller AD, Sirma H, Montalbano R, Ocker M, et al. Selective induction of apoptosis by HMG-CoA reductase inhibitors in hepatoma cells and dependence on p53 expression. Oncol Rep (2012) 28(3):1077-83. doi:10.3892/or.2012.1860

148. Borahay MA, Kilic GS, Yallampalli C, Snyder RR, Hankins GD, Al-Hendy A, et al. Simvastatin potently induces calcium-dependent apoptosis of human leiomyoma cells. J Biol Chem (2014) 289(51):35075-86. doi:10.1074/jbc.M114.583575

149. Borahay MA, Vincent K, Motamedi M, Sbrana E, Kilic GS, Al-Hendy A, et al. Novel effects of simvastatin on uterine fibroid tumors: in vitro and patient-derived xenograft mouse model study. Am J Obstet Gynecol (2015) 213(2):196.e1-8. doi:10.1016/j.ajog.2015.03.055

150. Borahay MA, Fang X, Baillargeon JG, Kilic GS, Boehning DF, Kuo YF. Statin use and uterine fibroid risk in hyperlipidemia patients: a nested 
case-control study. Am J Obstet Gynecol (2016) 215(6):750.e1-8. doi:10.1016/j. ajog.2016.06.036

151. Muck AO, Seeger H, Wallwiener D. Inhibitory effect of statins on the proliferation of human breast cancer cells. Int J Clin Pharmacol Ther (2004) 42(12):695-700. doi:10.5414/CPP42695

152. Martirosyan A, Clendening JW, Goard CA, Penn LZ. Lovastatin induces apoptosis of ovarian cancer cells and synergizes with doxorubicin: potential therapeutic relevance. BMC Cancer (2010) 10:103. doi:10.1186/1471-2407-10-103

153. Cho SJ, Kim JS, Kim JM, Lee JY, Jung HC, Song IS. Simvastatin induces apoptosis in human colon cancer cells and in tumor xenografts, and attenuates colitis-associated colon cancer in mice. Int J Cancer (2008) 123(4):951-7. doi:10.1002/ijc.23593

154. Monteith GR, Davis FM, Roberts-Thomson SJ. Calcium channels and pumps in cancer: changes and consequences. J Biol Chem (2012) 287(38):31666-73. doi:10.1074/jbc.R112.343061

155. Tsavaler L, Shapero MH, Morkowski S, Laus R. Trp-p8, a novel prostate-specific gene, is up-regulated in prostate cancer and other malignancies and shares high homology with transient receptor potential calcium channel proteins. Cancer Res (2001) 61(9):3760-9. Available from: http://cancerres. aacrjournals.org/content/61/9/3760.long

156. Prevarskaya N, Flourakis M, Bidaux G, Thebault S, Skryma R. Differential role of TRP channels in prostate cancer. Biochem Soc Trans (2007) 35 (Pt 1):133-5. doi:10.1042/BST0350133

157. Czifra G, Varga A, Nyeste K, Marincsák R, Tóth BI, Kovács I, et al. Increased expressions of cannabinoid receptor-1 and transient receptor potential vanilloid-1 in human prostate carcinoma. J Cancer Res Clin Oncol (2009) 135(4):507-14. doi:10.1007/s00432-008-0482-3

158. Zhuang L, Peng JB, Tou L, Takanaga H, Adam RM, Hediger MA, et al. Calcium-selective ion channel, CaT1, is apically localized in gastrointestinal tract epithelia and is aberrantly expressed in human malignancies. Lab Invest (2002) 82(12):1755-64. doi:10.1097/01.LAB.0000043910.41414.E7

159. Aydar E, Yeo S, Djamgoz M, Palmer C. Abnormal expression, localization and interaction of canonical transient receptor potential ion channels in human breast cancer cell lines and tissues: a potential target for breast cancer diagnosis and therapy. Cancer Cell Int (2009) 9:23. doi:10.1186/14752867-9-23

160. Dhennin-Duthille I, Gautier M, Faouzi M, Guilbert A, Brevet M, Vaudry D, et al. High expression of transient receptor potential channels in human breast cancer epithelial cells and tissues: correlation with pathological parameters. Cell Physiol Biochem (2011) 28(5):813-22. doi:10.1159/000335795

161. Yang SL, Cao Q, Zhou KC, Feng YJ, Wang YZ. Transient receptor potential channel C3 contributes to the progression of human ovarian cancer. Oncogene (2009) 28(10):1320-8. doi:10.1038/onc.2008.475

162. Wei C, Wang X, Chen M, Ouyang K, Song LS, Cheng H. Calcium flickers steer cell migration. Nature (2009) 457(7231):901-5. doi:10.1038/nature07577

163. Fiorio Pla A, Ong HL, Cheng KT, Brossa A, Bussolati B, Lockwich T, et al. TRPV4 mediates tumor-derived endothelial cell migration via arachidonic acid-activated actin remodeling. Oncogene (2012) 31(2):200-12. doi:10.1038/onc.2011.231

164. Yang S, Zhang JJ, Huang XY. Orai1 and STIM1 are critical for breast tumor cell migration and metastasis. Cancer Cell (2009) 15(2):124-34. doi:10.1016/j. ccr.2008.12.019

165. Peng HH, Hodgson L, Henderson AJ, Dong C. Involvement of phospholipase C signaling in melanoma cell-induced endothelial junction disassembly. Front Biosci (2005) 10:1597-606. doi:10.2741/1643

166. Baljinnyam E, De Lorenzo MS, Xie LH, Iwatsubo M, Chen S, Goydos JS, et al. Exchange protein directly activated by cyclic AMP increases melanoma cell migration by a Ca2+-dependent mechanism. Cancer Res (2010) 70(13):5607-17. doi:10.1158/0008-5472.CAN-10-0056

167. Burrus LW, McMahon AP. Biochemical analysis of murine Wnt proteins reveals both shared and distinct properties. Exp Cell Res (1995) 220(2):36373. doi:10.1006/excr.1995.1327

168. Willert K, Brown JD, Danenberg E, Duncan AW, Weissman IL, Reya T, et al. Wnt proteins are lipid-modified and can act as stem cell growth factors. Nature (2003) 423(6938):448-52. doi:10.1038/nature01611

169. Kurayoshi M, Yamamoto H, Izumi S, Kikuchi A. Post-translational palmitoylation and glycosylation of Wnt-5a are necessary for its signalling. Biochem $J$ (2007) 402(3):515-23. doi:10.1042/BJ20061476
170. Slusarski DC, Yang-Snyder J, Busa WB, Moon RT. Modulation of embryonic intracellular Ca2+ signaling by Wnt-5A. Dev Biol (1997) 182(1):114-20. doi:10.1006/dbio. 1996.8463

171. Medrano EE. Wnt5a and PKC, a deadly partnership involved in melanoma invasion. Pigment Cell Res (2007) 20(4):258-9. doi:10.1111/j.1600-0749. 2007.00383.x

172. Dissanayake SK, Weeraratna AT. Detecting PKC phosphorylation as part of the Wnt/calcium pathway in cutaneous melanoma. Methods Mol Biol (2008) 468:157-72. doi:10.1007/978-1-59745-249-6_12

173. Galli LM, Burrus LW. Differential palmit(e)oylation of Wnt1 on C93 and S224 residues has overlapping and distinct consequences. PLoS One (2011) 6(10):e26636. doi:10.1371/journal.pone.0026636

174. Guo Z, Linn JF, Wu G, Anzick SL, Eisenberger CF, Halachmi S, et al. CDC91L1 (PIG-U) is a newly discovered oncogene in human bladder cancer. Nat Med (2004) 10(4):374-81. doi:10.1038/nm1004-1139b

175. Wu G, Guo Z, Chatterjee A, Huang X, Rubin E, Wu F, et al. Overexpression of glycosylphosphatidylinositol (GPI) transamidase subunits phosphatidylinositol glycan class $\mathrm{T}$ and/or GPI anchor attachment 1 induces tumorigenesis and contributes to invasion in human breast cancer. Cancer Res (2006) 66(20):9829-36. doi:10.1158/0008-5472.CAN-06-0506

176. Nagpal JK, Dasgupta S, Jadallah S, Chae YK, Ratovitski EA, Toubaji A, et al. Profiling the expression pattern of GPI transamidase complex subunits in human cancer. Mod Pathol (2008) 21(8):979-91. doi:10.1038/modpathol.2008.76

177. Zunich SM, Douglas T, Valdovinos M, Chang T, Bushman W, Walterhouse D, et al. Paracrine sonic hedgehog signalling by prostate cancer cells induces osteoblast differentiation. Mol Cancer (2009) 8:12. doi:10.1186/1476-4598-8-12

178. Sims-Mourtada J, Yang D, Tworowska I, Larson R, Smith D, Tsao N, et al. Detection of canonical hedgehog signaling in breast cancer by 131-iodinelabeled derivatives of the sonic hedgehog protein. J Biomed Biotechnol (2012) 2012:639562. doi:10.1155/2012/639562

179. Fei DL, Sanchez-Mejias A, Wang Z, Flaveny C, Long J, Singh S, et al. Hedgehog signaling regulates bladder cancer growth and tumorigenicity. Cancer Res (2012) 72(17):4449-58. doi:10.1158/0008-5472.CAN-11-4123

180. Hitosugi T, Sato M, Sasaki K, Umezawa Y. Lipid raft specific knockdown of SRC family kinase activity inhibits cell adhesion and cell cycle progression of breast cancer cells. Cancer Res (2007) 67(17):8139-48. doi:10.1158/00085472.CAN-06-4539

181. Uno F, Sasaki J, Nishizaki M, Carboni G, Xu K, Atkinson EN, et al. Myristoylation of the fus1 protein is required for tumor suppression in human lung cancer cells. Cancer Res (2004) 64(9):2969-76. doi:10.1158/ 0008-5472.CAN-03-3702

182. Kaemmerer E, Gassler N. Wht lipidation and modifiers in intestinal carcinogenesis and cancer. Cancers (Basel) (2016) 8(7):E69. doi:10.3390/ cancers 8070069

183. Liu M, Sjogren AK, Karlsson C, Ibrahim MX, Andersson KM, Olofsson FJ, et al. Targeting the protein prenyltransferases efficiently reduces tumor development in mice with K-RAS-induced lung cancer. Proc Natl Acad Sci U S A (2010) 107(14):6471-6. doi:10.1073/pnas.0908396107

184. Raponi M, Lancet JE, Fan H, Dossey L, Lee G, Gojo I, et al. A 2-gene classifier for predicting response to the farnesyltransferase inhibitor tipifarnib in acute myeloid leukemia. Blood (2008) 111(5):2589-96. doi:10.1182/ blood-2007-09-112730

185. Baines AT, Xu D, Der CJ. Inhibition of Ras for cancer treatment: the search continues. Future Med Chem (2011) 3(14):1787-808. doi:10.4155/fmc.11.121

186. van de Donk NW, Schotte D, Kamphuis MM, van Marion AM, van Kessel $\mathrm{B}$, Bloem AC, et al. Protein geranylgeranylation is critical for the regulation of survival and proliferation of lymphoma tumor cells. Clin Cancer Res (2003) 9(15):5735-48. Available from: http://clincancerres.aacrjournals.org/ content/9/15/5735.long

187. Sjogren AK, Andersson KM, Khan O, Olofsson FJ, Karlsson C, Bergo MO. Inactivating GGTase-I reduces disease phenotypes in a mouse model of K-RAS-induced myeloproliferative disease. Leukemia (2011) 25(1):186-9. doi:10.1038/leu.2010.242

188. Wojciak-Stothard B, Potempa S, Eichholtz T, Ridley AJ. Rho and Rac but not Cdc42 regulate endothelial cell permeability. J Cell Sci (2001) 114(Pt 7):134355. Available from: http://jcs.biologists.org/content/114/7/1343.long 
189. Gelb MH. Protein prenylation, et cetera: signal transduction in two dimensions. Science (1997) 275(5307):1750-1. doi:10.1126/science.275.5307.1750

190. Sun J, Qian Y, Hamilton AD, Sebti SM. Both farnesyltransferase and geranylgeranyltransferase I inhibitors are required for inhibition of oncogenic K-Ras prenylation but each alone is sufficient to suppress human tumor growth in nude mouse xenografts. Oncogene (1998) 16(11):1467-73. doi:10.1038/ sj.onc. 1201656

191. Rocks O, Peyker A, Kahms M, Verveer PJ, Koerner C, Lumbierres M, et al. An acylation cycle regulates localization and activity of palmitoylated Ras isoforms. Science (2005) 307(5716):1746-52. doi:10.1126/science. 1105654

192. Xiao H, Qin X, Ping D, Zuo K. Inhibition of Rho and Rac geranylgeranylation by atorvastatin is critical for preservation of endothelial junction integrity. PLoS One (2013) 8(3):e59233. doi:10.1371/journal.pone.0059233

193. Montalvo SK, Li L, Westover KD. Rationale for RAS mutation-tailored therapies. Future Oncol (2017) 13(3):263-71. doi:10.2217/fon-2016-0363

194. Moorthy NS, Sousa SF, Ramos MJ, Fernandes PA. Farnesyltransferase inhibitors: a comprehensive review based on quantitative structural analysis. Curr Med Chem (2013) 20(38):4888-923. doi:10.2174/09298673113206660262

195. Berndt N, Hamilton AD, Sebti SM. Targeting protein prenylation for cancer therapy. Nat Rev Cancer (2011) 11(11):775-91. doi:10.1038/nrc3151

196. Braun T, Fenaux P. Farnesyltransferase inhibitors and their potential role in therapy for myelodysplastic syndromes and acute myeloid leukaemia. Br J Haematol (2008) 141(5):576-86. doi:10.1111/j.1365-2141.2008. 07099.x

197. Winter-Vann AM, Casey PJ. Post-prenylation-processing enzymes as new targets in oncogenesis. Nat Rev Cancer (2005) 5(5):405-12. doi:10.1038/ $\operatorname{nrc1612}$

198. Mohammed I, Hampton SE, Ashall L, Hildebrandt ER, Kutlik RA, Manandhar SP, et al. 8-Hydroxyquinoline-based inhibitors of the Rce1 protease disrupt Ras membrane localization in human cells. Bioorg Med Chem (2016) 24(2):160-78. doi:10.1016/j.bmc.2015.11.043

199. Lau HY, Ramanujulu PM, Guo D, Yang T, Wirawan M, Casey PJ, et al. An improved isoprenylcysteine carboxylmethyltransferase inhibitor induces cancer cell death and attenuates tumor growth in vivo. Cancer Biol Ther (2014) 15(9):1280-91. doi:10.4161/cbt.29692

200. Davda D, El Azzouny MA, Tom CT, Hernandez JL, Majmudar JD, Kennedy RT, et al. Profiling targets of the irreversible palmitoylation inhibitor 2-bromopalmitate. ACS Chem Biol (2013) 8(9):1912-7. doi:10.1021/ cb400380s

201. Ducker CE, Griffel LK, Smith RA, Keller SN, Zhuang Y, Xia Z, et al. Discovery and characterization of inhibitors of human palmitoyl acyltransferases. Mol Cancer Ther (2006) 5(7):1647-59. doi:10.1158/1535-7163. MCT-06-0114
202. Ganesan L, Shieh P, Bertozzi CR, Levental I. Click-chemistry based high throughput screening platform for modulators of Ras palmitoylation. Sci Rep (2017) 7:41147. doi:10.1038/srep41147

203. Hung MS, Chen IC, Lee CP, Huang RJ, Chen PC, Tsai YH, et al. Statin improves survival in patients with EGFR-TKI lung cancer: a nationwide population-based study. PLoS One (2017) 12(2):e0171137. doi:10.1371/ journal.pone.0171137

204. Wang A, Aragaki AK, Tang JY, Kurian AW, Manson JE, Chlebowski RT, et al. Statin use and all-cancer survival: prospective results from the Women's Health Initiative. Br J Cancer (2016) 115(1):129-35. doi:10.1038/ bjc. 2016.149

205. Habis M, Wroblewski K, Bradaric M, Ismail N, Yamada SD, Litchfield L, et al. Statin therapy is associated with improved survival in patients with non-serous-papillary epithelial ovarian cancer: a retrospective cohort analysis. PLoS One (2014) 9(8):e104521. doi:10.1371/journal.pone.0104521

206. Nayan M, Punjani N, Juurlink DN, Finelli A, Austin PC, Kulkarni GS, et al. Statin use and kidney cancer survival outcomes: a systematic review and meta-analysis. Cancer Treat Rev (2017) 52:105-16. doi:10.1016/j. ctrv.2016.11.009

207. Nevadunsky NS, Van Arsdale A, Strickler HD, Spoozak LA, Moadel A, Kaur G, et al. Association between statin use and endometrial cancer survival. Obstet Gynecol (2015) 126(1):144-50. doi:10.1097/AOG. 0000000000000926

208. Kozak MM, Anderson EM, von Eyben R, Pai JS, Poultsides GA, Visser BC, et al. Statin and metformin use prolongs survival in patients with resectable pancreatic cancer. Pancreas (2016) 45(1):64-70. doi:10.1097/ MPA.0000000000000470

209. Lee HS, Lee SH, Lee HJ, Chung MJ, Park JY, Park SW, et al. Statin use and its impact on survival in pancreatic cancer patients. Medicine (Baltimore) (2016) 95(19):e3607. doi:10.1097/MD.0000000000003607

210. Ramkumar S, Raghunath A, Raghunath S. Statin therapy: review of safety and potential side effects. Acta Cardiol Sin (2016) 32(6):631-9. doi:10.6515/ ACS20160611A

Conflict of Interest Statement: The authors declare that this review was written in the absence of any commercial or financial relationships that could be construed as a potential conflict of interest.

Copyright (c) 2017 Chen and Boehning. This is an open-access article distributed under the terms of the Creative Commons Attribution License (CC BY). The use, distribution or reproduction in other forums is permitted, provided the original author(s) or licensor are credited and that the original publication in this journal is cited, in accordance with accepted academic practice. No use, distribution or reproduction is permitted which does not comply with these terms. 